UDC 141.319.8:18

Georgia APOSTOLOPOULOU

\title{
ON THE DIALOGUE \\ OF AESTHETICS AND PHILOSOPHICAL ANTHROPOLOGY
}

\begin{abstract}
After the alleged 'ends' of metaphysics, of history, and of art, aesthetics reorganises the field of its enquiry. While retaining the question of the meaning of art for the human as the background justification of its theorising, aesthetics meets philosophical anthropology and enlarges its field. Philosophical anthropology explains that the instability of the human condition demands culture as the artificial stabilisation of the human world as well as of the human in the world. Expressivity, artificiality, and the aesthetic are interweaved with the meaning of the human world. In this context, pictures have priority over concepts and justify art as the eminent pictorial form of meaning. Since the human lives in nature and culture, the stabilisation of its open world is possible through creation of spatial correlates and of objects as well. Thus, aesthetics does need to expand enquiry beyond the discourse on art, so that it includes the issues concerning the aesthetic character of the human world and its spatial correlates. While Wolfgang Welsch and Richard Shusterman argue for a revision of aesthetics, Joseph Margolis and Helmuth Plessner support the stronger dialogue between philosophical anthropology and aesthetics in different ways. Further, Arnold Berleant explores aesthetics of human space.
\end{abstract}

Keywords: aesthetics, philosophical anthropology, aesthetics of spatiality, Wolfgang Welsch, Richard Shusterman, Helmuth Plessner, Joseph Margolis, Arnold Berleant.

After the alleged 'ends' of metaphysics, of history, and of art, aesthetics reorganises the field of its enquiry. It moderates their radical expression through interpretations that renew theorising on the question of art towards new forms of aesthetic creativity. Without historicist or normative demands, when considering art and the field of the aesthetic, aesthetics retains the question of the meaning of art for the human as the background justification of its status as a philosophical discipline. With reference to this question, aesthetics meets philosophical anthro- pology and can receive from the latter impulses sustaining its enlarged theorising.

Recent theories of aesthetics, while weakening the discourse of the end of art, perform a moderate shift towards issues and problems, which one could consider as anthropological ones. Thus, they stress that aesthetics is primarily of theory of senses, of perception, and of sensuous intuition as far as these constitute the significant approach to the world and to works of art. In this respect, these constitute the real way of the conscious human body towards aesthetic 
values and bear a primordial value for human existence.

The aforementioned theories liberate aesthetics from the burden of aesthetic historicism and of aesthetic essentialism as well. In some cases, the emphasis on sensation and perception is connected with the claim of revising aesthetics towards aisthetics, namely to a stronger theory of sensation and perception, which sets out that the latter offer the primordial access to reality. In this respect, starting from vital character of sensation and perception, Wolfgang Welsch criticises modern aesthetics as philosophy of art. He argues that aisthetics is a theory of that part of reality, which is accessible only to sensation and perception (Welsch, 1993, p.150; Welsch, 2012, p. 13). Thus, Welsch proposes anaesthetics as the complementary dimension of aesthetics'.

Nevertheless, it is necessary to explain what the term 'anthropological' could mean. First of all, this term points to a philosophical anthropology that came forward as a special sort of theorising and as a philosophical discipline through the works mainly of Max Scheler, of Helmuth Plessner, and of Arnold Gehlen that explore the question of the human by focussing on the issues of the living human body and of the relation of human to world. (Krüger \& Lindemann 2001; Fischer 2008). Further, they consider the relationship of nature and culture as possessing a systematic priority towards the relationship of culture and history. Subsequently, other philosophical theories, like these of new phenomenology or classical pragmatism, could be considered as theories within anthropological perspective if not as theories of philosophical anthropology themselves, even though they avoid these designations. After all, the classics of philosophical anthropology have taken into account pragma- tism, especially John Dewey's philosophy, while Scheler and Plessner had been members of phenomenological circles among Husserl's pupils and adherents in those times.

Thus, the moderate shift of contemporary pragmatist aesthetics to more or less anthropological questions has favourable presuppositions in the works of the classics of pragmatism. Even though in a distance from a comprehensive philosophical anthropology, Richard Shusterman's somaesthetics explores the significance which special activities, forms of training, or techniques of the human living body have for the positive feeling of life. In this way, Shusterman stresses bodily consciousness against intellectualist burdening that underestimates the primordial significance of human living body for the well-being of humans (Shusterman, 2000; Shusterman, 2008; Shusterman, 2012).

A totally different kind of dialogue of philosophical anthropology and aesthetics comes forth in Joseph Margolis' proposal for a philosophical anthropology that learns from art (Margolis, 2009). Aesthetics as philosophy of art offers to philosophical anthropology the conception of artificiality and of historicity. On the one hand, the human is artificial by nature, since it becomes the human as natural living being needs culture and language in order to be really the human. On the other hand, this 'hybrid' being, as Margolis characterises the human, becomes historicised. Therefore, the human perception changes in the course of history through culture. In this context, the varieties of the works of art as well as the intentional character of artistic creation indicate the complex of artificiality and historicity, of enculturation and acquaintance of language.

Thus, there are open complementarities among aesthetics and philosophical anthropolo- 
gy. Nevertheless, the convergence between philosophical anthropology and aesthetics does not mean some overlapping of these theories. On the contrary, Margolis retains their openness by developing a broader context concerning philosophy and the arts. It is of interest for the dialogue between pertaining theories that Margolis refers Plessner's philosophical anthropology, while stressing the inevitable relation of aesthetics to philosophical anthropology. Therefore, he mentions Plessner's 'ingenious' theories and endorses Plessner's argument of the artificiality of the human and of human world (Margolis, 2009, pp. 26-27). In fact, there are common points of consideration in Margolis' and in Plessner's philosophical anthropology. Both understand philosophical anthropology as a kind of theorising, which explores the human condition through philosophical categories and, in doing so, it avoids naturalistic reductionism. Their significant works open new worlds of theorising. The main difference of their theories is obvious. While Margolis takes the conception of artificiality from art, Plessner explains it through the differentiation of the forms of the organic. While Margolis uses artificiality as a category from the very beginning of his theory, Plessner considers the artificiality of the human and of the human world as an 'essential law' at the end of his philosophical anthropology. Altogether, artificiality is realised in the unity of difference between nature and culture. However, the dialogue between Margolis' and Plessner's theories can be inspiring and productive for aesthetics and philosophy of art as well.

Regarding artificiality and historicity, we may mention the typical stability of the human and of human world, which is linked to the relative stability of natural world. Margolis and Plessner would admit that the human as the em- bodied person as well as the human world are not only artificial but they also bear a typical yet elementary stability because they cannot escape the natural world and be only culture or only history. Nevertheless, this aspect leads to the question whether culture can recognise the relationship of humanity and nature and protect nature as the natural world of the human. Thus, aesthetics and philosophical anthropology can elucidate that the field of the aesthetic is broader than the everyday human life.

Plessner does not content himself with ascertaining the difference between the natural and the human in his philosophical anthropology. On the contrary, Plessner explores the specific characteristic of the human through a continuous differentiation of the relationship of organic forms to their surrounding field. In fact, he sets out a conception of nature and of life, which rejects the exclusively epistemological consideration of nature in terms of the sciences of nature. He emphasises the primordial relationship of the human to the nature and, depending on meaning, considers the lived experience of nature as prior to the scientific experience established through the sciences of nature. For him nature is the variety of primordial appearance, to which the human is not alien, since it is a living being.

In this respect, Plessner's early work on the unity of the senses manifests his attempt to explore nature as the 'nature-world' of the human, which includes the human as 'body and living body' (Körperleib) (Plessner, 1981ª). In this context, senses are no instruments, but their modalities are bridges between the human 'body-living body' (Körperleib) and spirit, namely between the natural world and the spirit indicating the creation of meaning and the understanding of meaning (Plessner, $1981^{\mathrm{a}}$, pp. 278,300 ). In this 
regard Plessner sets out a conception of hermeneutic philosophy of nature, which leads to his anthropological conception of nature (Apostolopoulou, 1988). It is worth mentioning that Plessner understands this early theoretical account as aesthesiology of spirit, but he characterises it later as anthropology of the senses. As regards aesthetics, aesthesiology should be the basis for aesthetics as a philosophy of art. Plessner is right that aesthetics needs a theory of sensation and perception. Altogether, he does not set out a theory aesthetics, but he deals later with problems of art mainly from the view of his philosophical anthropology. Thus, he explores an account of 'anthropology of music' or of 'anthropology of the actor' (Plessner, 1981 ${ }^{\mathrm{c}}$, pp. 184189, 399-417). Even though Plessner's hermeneutic philosophy of nature is close to the starting point of the aesthetics of nature, Plessner himself turns to an anthropological theory.

In his philosophical anthropology, Plessner emphasises that he avoids anthropocentrism by explaining that the human coexists with other living natural beings on earth. Nature belongs to the home of the human, but it is not the home of the human. Obviously, Plessner takes a step back historicity. Nevertheless, his purpose is to avoid the one-sided concentration of the definition of the human in the field of history (Plessner, $1981^{b}$ ). On the one hand, he does not intend to 'define' the human, namely to describe the substance of the human in terms of essentialism. On the other hand, he describes the human not simply as the conscious living body, but he emphasises the 'I' and the person. Therefore, the significant argument of the living body or of the conscious body, or of the self-conscious body we find in contemporary aesthetics includes a critical dynamic. However, it could perhaps be an abstraction from the view of Plessner's philo- sophical anthropology, because it does not bring to the fore the full description of the human, which Plessner sets out. Plessner's philosophical anthropology has an aesthetic dimension. For, it considers nature as appearance with qualities accessible to sensation, perception, and lived experience. Further, it introduces the distinction between spatiality and space, which receives a full meaning, while considering the human world. In addition, artificiality points to the interrelation of nature and art as $\tau \dot{\varepsilon} \chi \nu \eta \eta$ (techne).

Plessner starts from the description of the organism. He uses the category of 'positionality', which indicates the difference between the body as a thing ('Koerper') and the living body ('Leib') (Plessner, 1981'b, pp. 296, 393). Positionality is space seen from inside. While the body as a thing exists within its limits, the living body goes beyond its limits and vindicates its place within the life-field. In the latter case, there is a centre within the living body, which can determine the relation to life-field for the purpose for surviving. An organism is both, namely thing and living body, but the living body has the priority in considering the specific character of the organism as life subject. Further, the organism realises life within and beyond its limits, since it exists within the circle of the concrete life. The relation of the organism to space is differentiated. Positionality means the power of the subject of life towards space. The organism as body-thing exists in space. The living body is related to space, but it establishes its relation, because of its condition of life. In this respect, Plessner distinguishes between spatiality ('Raumhaft') and space ('Raum') (Plessner, 1981' , pp. 181, 326).

As Plessner explains, the animal has a self, it lives in the here and now, and it has consciousness, but does not have the lived experience of its own self or of its life-field. Life and conscious- 
ness achieve their highest level in the human. The distinctive category of the human condition is the 'eccentric positionality' and is connected with the consciousness of 'I' (Plessner, 1981' , p. 360). For, the 'I' takes a position towards the mentioned centre of the life subject, it is conscious of itself; it takes a distance from the self to the mentioned centre. At the same time, the 'I' conceives himself/ herself as a member of the shared world of persons. The relation to life field becomes the relation to world, to the inside world of feelings and dispositions, to the outside world of things, to the shared world of persons. Because of eccentric positionality, the human has to create its own world. It needs culture and norms, work, and continuous reorganisation of the space in which it can live and lives. The human as the human and the human world are artificial by nature (Plessner, $1981^{\text {b }}$, p. 383). Even though Plessner does not use the term, we may consider artificiality in its original meaning as $\pi$ oínoıs (poiesis), as creation of world, as artificial and artistic.

Altogether, the human creates and changes its world according to the understanding of spatiality and space from the viewpoint of life. Expressivity, artificiality, and the aesthetic are interweaved with the meaning of the human world. In this context, pictures have priority over concepts and justify art as the eminent pictorial form of meaning. Since the human lives in nature and culture, the stabilisation of its open world is possible through the creation of spatial correlates and of objects as well. Nevertheless, the meaning of the open human world receives its reality from the self-understanding and the world-understanding of the human. In this aspect, aesthetics does need to expand enquiry beyond the discourse on art, so that it includes issues concerning the aesthetic character of the human world and its spa- tial correlates, as they appear in everyday life and in different cultures.

Taking into account Plessner's distinction between spatiality and space, we have a starting point for the aesthetics of spatiality. It could be the frame for the aesthetic research of created spaces and on created space relations that indicate a complex relevance for the way humans understand their life world. Moreover, Plessner's philosophical anthropology contributes to a topology of human life in nature and in second nature, namely in culture. Without ignoring the differences, we may point to the Arnold Berleant's aesthetics of environment as another theoretical account of topology of human life, which argues for the revision of that kind of understanding the human, which does not refer to nature (Berleant, 1995; Apostolopoulou, 2004; Gkogkas, 2007).

The result of this research is that the dialogue between aesthetics and philosophical anthropology enriches both disciplines. The relation between such theoretical approaches is founded on significant questions that transcend the limits of particular disciplines. Since philosophy deals with the question of how humans are to understand themselves and their world, how humans ought and can live as humans, this dialogue will continue in new forms that also concern the arts and the aesthetic. In addition, the consideration of arts and the aesthetic enriches the question of the human and of the human world.

\section{REFERENCES}

Apostolopoulou, G. (1988). Zur praktischen Relevanz der Hermeneutik bei Plessner. In H. Bielefeldt, W. Brugger, \& K. Dicke (Eds.), Dimensionen menschlicher Freiheit. Johannes Schwart- 
länder zum 65. Geburtstag (pp. 19-31).

Tübingen: Attempto Verlag.

Apostolopoulou, G. (2003). Welterfahrung und Kunsterfahrung. In K. Gloy (Ed.), Kunst und Philosophie (pp. 43-59). Wien: Passagen Verlag.

Apostolopoulou, G. (2004). The Aesthetics of Environment as Aesthetics of the $\mathrm{Hu}$ man Space. Arnold Berleant's Contribution. In A. Berleant, Aesthetics of Environment (pp. 335-358, in Greek). Athens: Panayotis and Effie Michelis Foundation.

Berleant, A. (1995). Aesthetics of Environment. Philadelphia: Temple University Press.

Berleant, A. (2004). Aisthētikè tou periballontos. (Aesthetics of Environment, in Greek) (M. Antonopoulou, \& N. A. N. Gkogkas, Greek Trans.; G. Apostolopoulou, Scientific Supervision and Postscript). Athens: Panayotis and Effie Michelis Foundation.

Bielefeldt, H., Brugger, W., \& Dicke, K. (Eds.) (1988). Dimensionen menschlicher Freiheit. Johannes Schwartländer zum 65. Geburtstag. Tübingen: Attempto Verlag.

Fischer, J. (2008). Philosophische Anthropologie. Eine Denkrichtung des 20. Jahrhunderts. Freiburg / München: Verlag Karl Alber.

Gkogkas, N. (2007). Aesthetics and the Environment. Repatriating Humanity. Contemporary Aesthetics, 5(1), Retrieved May 30, 2018, from: https://digitalcommons.risd.edu/libera larts contempaesthetics/vol5/iss1/4/
Gloy, K. (Ed.) (2003). Kunst und Philosophie. Wien: Passagen Verlag.

Krüger, H.-P. \& Lindemann, G. (Ed.) 2001. Philosophische Anthropologie im 21. Jahrhundert. Berlin: Akademie Verlag.

Margolis, J. (2009). The Arts and the Definition of the Human. Towards a Philosophical Anthropology. Stanford: Stanford University Press.

Plessner, H. $\left(1981^{\mathrm{a}}\right)$. Die Einheit der Sinne. Grundlinien einer Aesthesiologies des Geistes. In: H. Plessner, Gesammelte Schriften, Vol. 3. Frankfurt a. M.: Suhrkamp.

Plessner, H. $\left(1981^{b}\right)$. Die Stufen des Organischen und der Mensch. Einleitung in die philosophische Anthropologie. In: $\mathrm{H}$. Plessner, Gesammelte Schriften, Vol. 4. Frankfurt a. M.: Suhrkamp.

Plessner, H. $\left(1981^{\circ}\right)$. Ausdruck und menschliche Natur. In: H. Plessner, Gesammelte Schriften, Vol. 7. Frankfurt a. M.: Suhrkamp Verlag.

Shusterman, R. (2000). Pragmatist Aesthetics. Living Beauty, Rethinking Art. Lanham: Rowman \& Littlefield Publishers.

Shusterman, R. (2008). Body Consciousness: A Philosophy of Mindfulness and Somaesthetics. Cambridge: Cambridge University Press.

Shusterman, R. (2012). Thinking through the Body: Essays in Somaesthetics. Cambridge: Cambridge University Press.

Welsch, W. (1993). Ästhetisches Denken. Stuttgart: Philipp Reclam.

Welsch, W. (2012). Blickwechsel. Neue Wege der Ästhetik. Stuttgart: Philipp Reclam. 